\title{
Corporate social responsibility research: the importance of context
}

\author{
Carol A. Tilt
}

\begin{abstract}
There has, in recent times, been an increasing interest in understanding corporate social (and environmental) responsibility (CSR) and, in particular, CSR reporting in developing countries. However, many of these studies fail to investigate fully the contextual factors that influence CSR and reporting in those countries, preferring to rely on theories and hypotheses developed from studies undertaken in the West, particularly the US, UK and Australasia. It may be argued that this is appropriate as many emerging economies are experiencing growth and moving towards having a more market-based orientation. Notwithstanding this, a large number of these countries have an entirely different socio-political environment, with different political regimes, legal systems and cultural influences. These factors have a significant effect on the applicability of theories such as stakeholder theory, legitimacy theory and accountability theory, which are commonly used to explain the phenomenon of reporting. In State Capitalist countries, such as China, an important influence on companies is the political ideology that underpins the nation's government. The nature and impact of ideology and hegemony in China has been under-studied and, therefore, investigating how the ideology, and competing forces that may mitigate its influence, manifest themselves in Chinese reporting are essential. In the Middle East, countries such as Saudi Arabia have no free press, are ruled by a royal family, have a market dominated by the oil industry, and potential religious influences. Such socio-cultural differences mean societies develop different understandings of concepts such as sustainability and social responsibility. Finally, countries such as Sri Lanka have some similarities to other developing countries, but their economy is set against a background of a recent civil war - operating in a post-conflict economy is a factor rarely considered in social and environmental disclosure, yet has important influence on policy in these areas.

This paper discusses three contextual issues that warrant more and improved consideration in CSR research, with particular emphasis on CSR reporting research.
\end{abstract}

Keywords: Corporate social responsibility, Corporate environmental reporting, Government, Ideology, Hegemony, Politics, State capitalism, Economic development, Developing countries, China, Sri Lanka, Middle East

\section{Background}

More and more corporations worldwide are involved in corporate social responsibility activities, and as a result are providing more social and environmental information to the public. Following from this, CSR disclosure, or reporting, has become one of the major fields of investigation by accounting scholars (Deegan 2009; Mathews 1997; Tilt 2001). Research that considers both CSR activity and CSR reporting has traditionally focused on companies in more developed economies, predominantly the US, UK, Australia

Correspondence: Carol.Tilt@unisa.edu.au

School of Commerce, University of South Australia Business School, GPO Box 2471, Adelaide 5001, South Australia and New Zealand (Burritt and Schaltegger 2010; Frost et al. 2005; Gray 2006; Gurvitsh and Sidorova 2012; Othman and Ameer 2009; Patten 2002; Sahay 2004), but recently there has been increasing interest in understanding the phenomenon in developing countries particularly as they experience growth and move towards a more capitalist orientation (Sumiani et al. 2007). Of the research that does exist, a number of papers suggest that 'country' is a determinant for CSR involvement and for the level of disclosure, but do not go much further.

Many of the studies of developing countries however, choose a framework for their investigation based on those shown to be meaningful for explaining disclosure 
in developed, capitalist economies. That is, they fail to investigate fully the contextual factors that influence firms and their reporting in those countries that have a different social, political, legal and/or cultural context.

It may be argued that this is appropriate as many emerging economies are experiencing growth and moving towards having a more market-based orientation. However, this is rarely acknowledged or questioned in these papers. Yet, it is reasonable to suggest that these factors have a significant effect on the applicability of theories such as stakeholder theory, legitimacy theory and accountability theory, which are commonly used to explain the phenomenon of reporting.

The majority of the world's population lives in developing countries and each country experiences its own unique social, political and environmental issues (United Nations 2013). These countries are in the process of industrialisation and are often characterised by unstable governments, higher levels of unemployment, limited technological capacity, unequal distribution of income, unreliable water supplies and underutilised factors of production. As a result of rapid industrial development, policies are pursued that aim to attract greater foreign investment, and the investors are often keen to start benefitting from fiscal incentives and cheap labour. While these strategies make economic sense, they have adverse social and environmental effects, including the use of child labour, low or unpaid wages, unequal career opportunities, occupational health and safety concerns, and increased pollution.

In a review of the literature on determinants of CSR reporting (Morhardt 2010), reports that research on the impact of different variables in different regions is inconclusive due to the lack of enough studies. Factors that may influence CSR disclosure practices fall broadly into internal and external (Fifka 2013; Morhardt 2010), but are commonly classified further as (Adams 2002: p224):

- Corporate characteristics, such as size, industry group, financial/economic performance and share trading volume, price and risk;

- General contextual factors, such as country of origin, time, specific events, media pressure, stakeholders and social, political, cultural and economic context; and

- Internal contextual factors, including different aspects of corporate governance.

While CSR reporting has been studied by a large number of scholars, only a few fall into the second of the categories above, and consider context in detail. This is particularly relevant when considering developing countries. A few papers have specifically reviewed studies on developing countries. For example, (Belal and Momin
2009) categorise the work on developing countries into three groups: studies of the volume or extent of reporting; studies of the perceptions of CSR reporting by managers; and studies of the perception of CSR reporting by stakeholders. In all the studies reviewed there is little discussion of the context, other than a description of the country, and no real thought about the theoretical assumptions being made.

This paper presents a discussion of the different contextual issues or factors that show some evidence or potential to influence CSR and reporting in developing countries. It focusses on three specific issues and provides a research agenda for future consideration of the influence of context in CSR reporting research. The paper is structured as follows. The next section introduces some broad contextual factors that warrant consideration in the literature on CSR reporting. Next, three specific contextual issues are examined: the role of political ideology and hegemony; the influence of cultural understandings; and the impact of historical economic context. Finally, by way of conclusion, some recommended areas for further research are suggested.

\section{Contextual considerations}

Adams (2002) talks about the social, political, cultural and economic context, so some consideration of what this might mean is needed as each of these concepts themselves cover a variety of aspects, and indeed overlap. While papers may talk about the 'social context' in which the companies being examined operate, this is not well defined and little consideration is given to what this means. Some things that could be more explicitly considered include, inter alia: the role of the press; the status of women; the legal/justice system; the level of corruption; the level of government control, cultural understandings; and so on. This paper chooses to highlight three of these areas, and these are discussed briefly below in broad terms, followed by a discussion of some specific aspects of each identified as providing fertile grounds for future research.

\section{Political system}

Assumptions are often made about capitalist systems, whether explicit or implicit, as the vast majority of work on CSR reporting has been done in the Western context. However, there is little research looking at CSR reporting in socialist or communist countries. Some work has been undertaken on China (Dong et al. 2014; Gao 2011; Situ and Tilt 2012), but this work often applies the same conceptual frameworks as Western studies. What about the influence of ideology, and hegemony?

\section{Sociocultural environment}

Human beings have "distinctive cultural (learned) characteristics, histories and responses to their environment" 
and the term 'sociocultural' is commonly used in anthropological research to describe these and the "interactions and processes" that this involves (Garbarino 1983: p1). Some general studies of culture and CSR using Hofstede exist (Silvia and Belen 2013), but an in-depth analysis of different understandings and conceptions of terms such as CSR as a result of sociocultural influences is lacking. The work that does examine specific factors often suggests that the Western concept of CSR does not fit these contexts (Wang and Juslin 2009).

The majority of work that considers sociocultural factors has looked mainly at religious aspects of CSR, most commonly by reviewing reporting by Islamic organisation, such as Islamic banks (Maali et al. 2006; Siwar and Hossain 2009; Sudarma et al. 2010). The teachings of many religions focus on social responsibility, the relationship with the natural environment, treatment of others, fairness, justice, etc., so there is a natural expectation that religion-based organisations may be more likely to engage in CSR and CSR reporting. A more nuanced consideration of how this manifests itself in different societies would improve understanding of the drivers and motivations of these activities. Similarly, other sociocultural factors, such as national identity, values, social organisation and language, could be incorporated.

\section{Stage of development}

The emerging literature on CSR reporting outside the Western world examines countries that are 'developing' (Belal and Momin 2009; Momin and Parker 2013), but little depth is included about where they are in their development journey and how the potential conflict between economic and social goals impacts CSR or CSR reporting. Rostow's (1962) Stages of Economic Growth model suggests there are five stages (traditional society, preconditions for take-off, take-off, drive to maturity, and age of high or mass consumption), yet most literature on CSR classifies countries only into developed or developing. The 'developing' classification potentially includes countries that are in Rostow's first, second or third stage which may have an impact on their response to CSR issues. In addition to economic variables however, the United Nations also produces a Human Development Index (HDI) which considers life expectancy, education and income to measure how social, as well as economic, development (UNDP 2015). Both these concepts are important for consideration of CSR.

Importantly, consideration of just one or two aspects of these three broader contextual issues may result in misinterpretation of the results. Often these things interact, for example, social issues often cross over with cultural and religious impacts, or even with political influence where the regime is more hegemonic. It is thus important to consider, or at least acknowledge, the holistic nature of the context of the phenomenon being examined.
It is beyond the scope of this paper to discuss all of the issues raised here although this would be an important part of a larger research program. Therefore, three particular contextual issues, and three specific contexts, are the focus of this paper: the role of political ideology and hegemony (China); the influence of cultural understandings (Middle East); and the impact of historical economic context (Sri Lanka).

\section{Politics, ideology and state control}

Ideology is a set of common beliefs that are shared by a group of people, and is "the fundamental social beliefs that organize and control the social representations of groups and their members" (Van Dijk 2009: p78). Countries such as China provide a fertile research setting to examine the influence of ideology, and hegemonic approaches of influencing CSR, which have been missing from most CSR research in the region.

The Chinese political model has some unique characteristics. Among these is the dominance of 'the party state, which exercises control in different forms over most aspects of the economy that is unmatched when compared to other state capitalist economies. Political leaders use a variety of tools (Bremmer 2010) and it is the combination of three particular tools that sets apart the Chinese system: the exercise of control as a dominant shareholder, the ability to appoint key positions in major firms, and the means to influence decisionmaking via ideology. First, the party exerts shareholder power over state-owned enterprises (SOEs). Chinese SOEs play an instrumental role in society (Du and Wang 2013) and make up around $80 \%$ of the stock market (Economist T 2012). As protecting the environment is a major part of the guiding ideology and the nation's policy, SOEs are likely to be keen to provide CER. Second, the party exercises power over the appointment of the senior leadership in SOEs (Landry 2008). This has resulted in control as they are "cadres first and company men second. They care more about pleasing their party bosses than about the global market" (Economist $\mathrm{T}$ 2012: p6). Third, party control is exercised through ideology. The party has cells in most larger firms, whether private or state-owned, which influence business decisions made at board meetings. Given that China considers the Marxist-Leninist-Maoist ideology as crucial this distinguishes it most significantly from other varieties of state capitalism that have a more liberaldemocratic flavour.

There is some evidence that the first form of party control has been declining in recent times with the number of SOEs under the SASAC's control halving over the last decade (Mattlin 2009). Similarly, since 1999, the share of SOEs in the economy has declined from $37 \%$ to less than $5 \%$. This results in greater use of 
regulation and ideological hegemony to achieve its aims, yet most CSR research still uses state-ownership as a proxy for all types of state control.

Even after economic reform, ideology in China was still pervasive (Lieber 2013). Lieber (2013) argues that ideology is widely used to signal loyalty and the government is good at using ideology to "control and direct key vocabularies... (and) vague ideological language can create a climate of uncertainty thus increasing the range of a control regime" (Lieber 2013: p346). However, the prevailing ideological themes in China are dynamic. In particular, most recently, new ideological themes have developed to respond to the changes in society. When economic reform began, "building up a socialist market economy with specific Chinese characteristics" was the guiding ideology (Zhang 2012: p25). As such, economic growth was the country's priority, but in 2005, "building up a harmonious society became the prevailing ideology" (and CSR is a key element of this resolution).

Ideology is used by the Chinese government to exert control over businesses. Traditionally, the government has "been considered a source of moral authority, official legitimacy and political stability...and ...political language has been vested with an intrinsic instrumental value: its control represents the most suitable and effective way first to codify, and then widely convey, the orthodox state ideology" (Marinellin 2012: p26). The language "developed and used by party officials ... consists of 'correct' formulation, aims to teach the 'enlarged masses' how to speak and, how to think" (Marinellin 2012: p26). The idea of the importance of a 'Harmonious Society' is the "re-contextualized discourse in response to the emergent issues in the changing social stratification order" (Zhang 2012: p33). As a result, Chinese companies have been noticeably adopting the language of social concern and environmental protection.

It may therefore be suggested that CSR reporting in China is directly a response to the government's ideological hegemony. However, the story is not as straightforward as it may first appear, for two reasons. First, despite a great deal of commitment to social and environmental regulation in China, implementation of these regulations has been limited. Second, as China enters a phase of continued economic development, Western influences may begin to have a moderating effect on the strength of the ideology.

The Chinese economy has grown rapidly in terms of gross domestic product (GDP) (World Bank 2016). The economic reforms that took place over the past decades were motivated substantially by the Chinese central government, and recent scholars have noted the positive role that ideology played in driving those reforms, notwithstanding that economists historically view ideology as "distorting... knowledge, judgment and decision making" (Lieber 2013: p344).
With economic reform however, has come substantial environmental degradation which in turn has led to poor health outcomes for much of society generally. This led to a high level of commitment to environmental regulation in particular from as early as the 1990, followed by the release of even more rigorous regulations on environmental protection in the 2000s. However, despite the high commitment made by the Chinese central government, implementation of these policies is quite poor (Bina 2010). In terms of environmental regulation, for example, the implementation problems stem from a number of areas, including: the position of environmental protection agencies in the political framework; conflict between central and local governments; and supervision issues. The system of supervision of local environmental departments is a key problem (Bina 2010). When an environmental department is set up in the central government, corresponding environmental departments are set up in local governments. Ideally, these local departments should be agencies of the central department, deliver the central environmental department's strategies, and supervise local environmental protection implementation. In reality, the local environmental departments are subservient to the local rather than central governments. All their financial support and staff appointments come from local governments. Therefore, rather than supervising local environmental protection implementation, the local environmental departments become "rubber stamps" for local governments (Zheng 2010). Therefore, it is unlikely that there will be efficient enforcement of environmental laws, regulations and policies at the local level (Bina 2010; Zheng 2010).

Finally, as China heads towards a market economy, government intervention becomes a policy choice, and markets function as a tool of national interest (Zhao 2011). However, as Chinese firms become more involved with foreign trading partners and markets, their reporting activity is also influenced by foreign and global organisations, leading to potential tension between demonstrating commitment to state ideological goals and meeting the requirements of global stakeholders.

Given the complexity of the context, research into CSR reporting in China needs to take into account the specific aspects of Chinese politics and culture in order to provide a nuanced understanding, and ultimately an improvement, of CSR reporting activities. However, a review done of the literature on CSR in by Chinese showed that it is very descriptive with little depth and much of the CSR literature is conceptual, descriptive, or argumentative in nature (Guan and Noronha 2013). The authors noted proper research methodologies are not systematically applied in some studies, and supporting theories are lacking. In the non-Chinese studies on China, there is also a predominance of papers on 
determinants and volume of reporting (Situ and Tilt 2012), with very few considering broader contextual factors, other than a few that look at specific cultural attributes (e.g., Rowe \& Guthrie 2009).

\section{Sociocultural understandings}

Notwithstanding a move towards a market orientation of many developing countries, such as in China as outlined above, conceptions of CSR by management of companies in these countries may be quite different to those in the West (Wang and Juslin 2009). These differing conceptions may be a result of differing values and attitudes, language, religion or identity. Even specific elements of CSR are conceived of differently, for example in China, the main understanding of sustainability is in terms of environmental protection (Situ et al. 2013, 2015). These socioculturally derived understandings are inevitably reflected in their reporting.

In another example, in the Middle East, the predominant perception of CSR is that it simply means philanthropic donations. In this region, the issue of social responsibility is relatively new, and as such the number of studies of CSR and CSR reporting in the Gulf region is growing (Al-Khatar and Naser 2003; AlNaimi et al. 2012; Emtairah et al. 2009; Mandurah et al. 2012; Marios and Tor 2007; Minnee et al. 2013; Nalband and Al-Amri 2013; Naser et al. 2006; Naser and Hassan 2013; Qasim et al. 2011; Sangeetha and Pria 2012). Many of these studies do not consider the cultural context to a very great extent as the research is emerging and focusses on perceptions. For example, Mandurah et al. (2012) and Emtairah et al. (2009) explored managerial perceptions of the concept of CSR in Saudi Arabia and found that managers are aware of the concept, but there is little connection between the managerial level perceptions and firms' workforce. The authors describe CSR as being in its infancy phase, which limits the understanding of the concept to the view that CSR simply means being philanthropic. This indicates a different, and perhaps less developed, understanding of the concept in the region compared with the West, but the reasons for this, and the consequences for CSR reporting, are under-explored. Some authors suggest the narrow use of the term is because of the religious obligations towards society, (Visser 2008). There is only minimal evidence of any CSR practices other than philanthropy-based or any strategic approaches to CSR for long-term benefits (Visser 2008), but the trend is increasing and the forms that philanthropy takes is expanding.

It has also been argued that politics plays a significant role in increasing the awareness of CSR in the Arab world. Avina (2013) suggests that the perception of CSR in the Middle East changed after the Arab spring event, for both local and international firms. The term CSR more than a decade ago had little meaning to the public (Visser 2008) but since the Arab spring, the sense of social responsibility among civil society and the corporate sector has increased Avina 2013). Firms realised that they play a role in social responsibility, not just governments, and recognised that CSR should go beyond just donations to charitable causes (Avina 2013). Ronnegard (2013), however, predicts that CSR in the Middle East will not mimic the Western concept because of the strong influence of culture and religion in the region. Moreover, the influence of stakeholders in the Middle East is considered to be limited due to there being a lack of free press, few lobby groups and the different cultural attributes of employees and consumers. Some studies in Gulf countries have however, suggested that stakeholders, such as government and charitable organisations, may have an impact on firms' behaviour (Emtairah et al. 2009; Naser et al. 2006). Others suggest that CSR may have developed as a concept due to the increase of foreign direct investment into Arab countries, the trend of shifting family and government owned firms into the public domain, and the globalisation of the region's large national firms.

From the limited studies that have been undertaken, there is evidence of CSR reporting by Gulf country companies, with human resources and community involvement being the dominant themes in may reports AbuBaker and Naser 2000). Thus, understanding of motivations for CSR reporting is not yet well developed and few existing studies consider the different level of stakeholder pressure in the region. This suggests that more research is needed on the formation of notions of CSR within specific contexts. This region is of particular interest because, according to the Human Development Report (HDI 2013), countries in the region are classified as high, or very high, in human development. That is, they are not only trying to develop and improve their economy, but are also trying to improve the quality of life of their citizens (Ramady 2010). The overall outlook of these countries indicates that they are performing well, however, Fadaak (2010) notes that identifying poverty lines is a challenge because of a lack of a clear definition of poverty in the region. There are no official reports considering poverty or other social problems and no GCC (Gulf Cooperation Council) countries were found in the list of the World Bank Database in relation to the poverty rate.

Similarly, in other developing countries the importance of local economic, cultural, and religious factors that shape the business environment, and understandings of charity and philanthropy, need to be taken into account. Empirical work in this area is lacking (LundThomsen et al. 2016). In Sri Lanka, for example, "the most common arguments used to 'sell' the business case 
Table 1 CSR and developing countries: political, economic and sociocultural variables for a future research agenda

\begin{tabular}{|c|c|c|}
\hline Classification & Variable & Interactions \\
\hline \multirow[t]{5}{*}{ Political } & Political System & \multirow{8}{*}{$\begin{array}{l}\text { Some political variables could be considered sociocultural as, for example, political ideology impacts } \\
\text { national identity and values }\end{array}$} \\
\hline & Ideology & \\
\hline & Hegemony & \\
\hline & State Ownership & \\
\hline & Propaganda Level & \\
\hline \multirow[t]{9}{*}{ Sociocultural } & Language & \\
\hline & Level of urbanisation & \\
\hline & Educational development & \\
\hline & Secularism & \multirow{8}{*}{$\begin{array}{l}\text { Sociocultural factors are related to economic development, for example, education level is highly } \\
\text { correlated with industrialisation and technological advancement }\end{array}$} \\
\hline & Freedom of the press & \\
\hline & Access to information & \\
\hline & $\begin{array}{l}\text { Homogeneity of values } \\
\text { and attitudes }\end{array}$ & \\
\hline & $\begin{array}{l}\text { Existence of a national } \\
\text { figurehead }\end{array}$ & \\
\hline & National identity & \\
\hline \multirow[t]{5}{*}{ Economic } & $\mathrm{HDI}$ & \\
\hline & FDI & \\
\hline & Access to markets & \multirow[t]{3}{*}{ Economic variables impact on, and are impacted by, politics } \\
\hline & Industrialisation level & \\
\hline & Technology & \\
\hline
\end{tabular}

for CSR and CP [Corporate Philanthropy], for example an improved brand image, increased market or customer share, employee retention, mitigated regulatory risks, and reduced tax burden, are considered mostly irrelevant" (Global Insights 2013: p1). Business leaders engage in CSR for a range of business, humanitarian, social, religious, and political reasons. Key amongst them is a belief that 'giving back' to society discharges religious obligations to the poor, and an awareness that being seen to contribute to national development goals is important (Global Insights 2013). Hence, the conception of CSR in this region is culturally determined, but also shaped by the economic environment.

\section{Economic development}

As well as government control, culture and political factors, the stage of economic development a country is in is also an important contextual factor that may impact CSR reporting. In China, as discussed above, the drive for economic reform led directly to environmental impacts which needed to be addressed. A number of other developing countries have been examined for their reporting on CSR issues, particularly from the Asian region (Andrew et al. 1989; Elijido-Ten et al. 2010), India (Mishra and Suar 2010; Raman 2006; Sahay 2004), and Bangladesh (Belal and Owen 2007; Belal and Roberts 2010; Khan 2010; Muttakin et al. 2015).
While these countries are classified as developing (IMF 2015), Bangladesh and India score only medium for human development. Another country in the region, Sri Lanka, has a high rating on the HDI, and has been exhibiting extensive growth since the end of a 30-year war (WPR 2015). Thus, exhibiting both economic and social growth aspects makes it an interesting case for studying CSR.

Sri Lanka has a population of over 20 million and foreign companies have increased their investments with one billion US dollars in direct foreign investments in 2013 alone (BOI). Classified as a middle income developing country, the challenge for Sri Lanka is to achieve high economic growth without causing irreversible damage to the environment and while continuing to eliminating social issues such as poverty, malnutrition and poor workplace ethics (Goger 2013). In addition, Sri Lanka also has a long history of corporate philanthropy, largely led by individuals whose values and actions stem from religious and cultural views (Beddewela and Herzig 2013) but has recently seen an increase in private firms offering development-related initiatives. Public infrastructure projects have been the main element of postwar economic planning, but there still remains rural poverty in the country. Thus, the primary motivation for CSR and philanthropy in Sri Lanka is poverty reduction, particularly for children and youth, social welfare 
organisations like orphanages and elderly homes, hospitals and health services, and veterans' charities (Global Insights 2013). Thus, the economic, cultural, and political context means that these poverty rates have fallen (data indicates that the rate went from approximately $20 \%$ in 2000 to under $9 \%$ in 2013) and that inflation has slowed (Wijesinha 2014), so opportunities for private businesses to contribute to infrastructure abound. However, these private, development-orientated, CSR initiatives have often failed to deliver their aims and there is considered to be a danger that they may in fact perpetuate the causes of poverty and ethnic and religious conflict given their ties to particular ethnic groups (Global Insights 2013).

Notwithstanding this environment, the topic of CSR reporting in Sri Lanka has received relatively little research attention compared to other parts of the world (see Belal and Momin 2009, for a review). In terms of motivations for CSR, there is some evidence that firms in which senior management have a positive outlook towards social and environmental practices tend to disclose more on these aspects, as compared to other firms (Fernando and Pandey 2012). However, reporting on CSR initiatives is not mandatory thus it is likely that any voluntary reporting by Sri Lankan firms will vary significantly. One study of reporting was conducted by Senaratne and Liyanagedara (2012) who examined the level of compliance with Global Reporting Initiative (GRI) guidelines in the disclosures of publicly listed companies, selected from seven business sectors. The authors conclude that the level of compliance with the GRI is low and that disclosures vary significantly amongst the companies, potentially reflecting varying commitment to CSR. Similarly, a longitudinal study across five years (20052010) was carried out by Wijesinghe (2012) to identify trends in CSR reporting in Sri Lanka and the study identified an increasingly positive trend, predicting similar levels of disclosures provided by companies in developed countries. The few studies that have been conducted examining the predominance of reporting in Sri Lanka, mostly examining multinational companies, conclude that CSR reporting is gaining momentum in Sri Lanka but is still emerging as the concept of CSR itself emerges (Beddewela and Herzig 2012; Hunter and Van Wassenhove 2011).

\section{Conclusion and a future research agenda}

As more and more research on CSR in developing countries emerges in the academic literature, it is important to ensure that appropriate consideration is given to the context in which the research takes place. Examination of CSR and CSR reporting practices without contextualisation could perpetuate flawed understandings that are based on evidence from research in the developed world. Different political, social, cultural and economic environments impact on the both the development of, and reporting of, CSR activities and consequently impact on the value of these activities to benefit society and the natural environment.

A suggested agenda for future research, that considers context in more depth, includes:

1. Consideration of ideological and hegemonic regimes and their attitude towards CSR. This research would consider potential positive and negative impacts of the political and governance system. In China, for example, the potential for Communist Party ideology to increase environmental protection and improve social conditions is vast, and is starting to be seen to have a strong impact on firm behaviour. Examination of this over time will provide an important contribution to understanding the role of government beyond the more common analysis of environmental protection regulation.

2. Greater examination of sociocultural variables in different countries, beyond analysis of religious influence, and beyond the use of Hofstede. Understandings of concepts such as CSR in countries in Asia, the Middle East and the Asian sub-continent, are known to differ from those in the West, so understanding their potential to lead to better (worse) CSR outcomes is important. The variety of variables that could be included is vast, but some clearly important issues include: language, secularism, freedom of the press, access to information, homogeneity of values and attitudes, and the existence of a national figurehead or identity.

3. Longitudinal examination of the process of economic development. Countries where the economy is developing rapidly, such as China and the Middle East; and countries where the historical economic context differs dramatically, such as in Sri Lanka where the need for development is borne out of conflict, provide rich backgrounds to consider how CSR is developing alongside economic developments.

A comprehensive framework for examining these, and other, potential factors that influence CSR and CSR reporting in developing countries does not exist, but Table 1 attempts to provide a preliminary outline of some factors that could comprise such a framework, and be used to guide future research. As mentioned earlier, it is important to note, however, that these variables are not discreet and are likely to interact with each other. This is noted in the table as a reminder that the classifications are somewhat artificial and that acknowledgement of a more holistic consideration is important.

These are clearly only a selection of opportunities for CSR research on developing nations and emerging 
economies. Calls for more work on these factors have continued since Adams' (2002) original call, but there is still vast scope to improve our understanding of CSR practice throughout the world (Fifka 2013), where much of the social and environmental damage is taking place.

Importantly, research of this kind must be transdisciplinary as perspectives from areas such as political science, philosophy and economics are essential. Only with in-depth, contextualised understandings can improvements to the nature of CSR activity be implemented.

\section{Competing interests}

The author declares that she has no competing interests.

\section{Acknowledgements}

It is important to acknowledge that this paper provides an overview of a larger research program currently being undertaken by a team of doctoral students at Flinders University and the University of South Australia. Credit must be given to Ms Hui Situ (Flinders University) who is researching environmental reporting in China, Mr Abdullah Silawi (Flinders University) who is researching social responsibility reporting in the Gulf region, and Ms Dinithi Dissanayake (University of SA), who is researching environmental disclosure in Sri Lanka.

Received: 14 March 2016 Accepted: 18 May 2016 Published: 5 July 2016

\section{References}

1. Abu-Baker, N., \& Naser, K. (2000). Empirical evidence on corporate social disclosure (CSD) practices in Jordan. International Journal of Commerce and Management, 10(3/4), 18-34.

2. Adams, C. (2002). Internal organisational factors influencing corporate social and ethical reporting: beyond current theorising. Accounting Auditing Account Journal, 15(2), 223-50.

3. Al-Khatar, K., \& Naser, K. (2003). User's perceptions of corporate social responsibility and accountability: evidence from an emerging economy. Managerial Auditing Journal, 18(6/7), 538-48.

4. AlNaimi, H. A., Mohammed, H., \& Momin, M. A. (2012). Corporate social responsibility reporting in Qatar: a descriptive analysis. Social Responsibility Journal, 8(4), 511-26.

5. Andrew, B. H., Gul, F. A., Guthrie, J., \& Teoh, H. Y. (1989). A note of corporate social disclosure practices in developing countries: the case of Malaysia and Singapore. The British Accounting Review, 21(01), $371-76$.

6. Avina, J. (2013). The evolution of Corporate Social Responsibility (CSR) in the Arab Spring. The Middle East Journal, 67(1), 77-92.

7. Beddewela, E., Herzig, C. (2012). Corporate social reporting by mncs' subsidiaries in Sri Lanka. Paper presented at Accounting Forum.

8. Beddewela, E., \& Herzig, C. (2013). Corporate social reporting by MNCs subsidiaries in Sri Lanka. Accounting Forum, 37(2), 135-49.

9. Belal, A., \& Momin, M. (2009). Corporate social reporting in emerging economies: a review and future direction. Research in Accounting in Emerging Economies, 9, 119-45.

10. Belal, A. R., \& Owen, D. L. (2007). The views of corporate managers on the current state of, and future prospects for, social reporting in Bangladesh: an engagement-based study. Accounting, Auditing \& Accountability Journal, 20(3), 472-94.

11. Belal, A. R., \& Roberts, R. W. (2010). 'Stakeholders' perceptions of corporate social reporting in Bangladesh. Journal of Business Ethics, 97(2), 311-11-24.

12. Bina, O. (2010). Environmental governance in China: weakness and potential from an environmental policy integration perspective*. The China Review, 10(1), 207-40.

13. BOI. Why Sri Lanka Now?. http://www.investsrilanka.com/: Board of investment of Sri Lanka. nd. Accessed 1 Feb 2016.

14. Bremmer, I. (2010). The end of the free market: who wins the war between states and corporations. European View, 9(2), 249-52.

15. Burritt, R. L., \& Schaltegger, S. (2010). Sustainability accounting and reporting: fad or trend? Accounting, Auditing \& Accountability Journal, 23(7), 829-46.
16. Deegan, C. (2009). Extended systems of accounting - the incorporation of social and environmental factors within external reporting. In Financial accounting theory (pp. 378-425). Sydney: McGraw-Hill.

17. Dong, S., Burritt, R., \& Qian, W. (2014). Salient stakeholders in corporate social responsibility reporting by Chinese mining and minerals companies. Journal of Cleaner Production, 84, 59-69.

18. Du, J., Wang, Y. (2013). Reforming SOEs under China's State Capitalism, Unfinished Reforms in the Chinese Economy. p. 1-38.

19. Economist, T. (2012).State capitalism, The economist. p. 1-14.

20. Elijido-Ten, E., Kloot, L., \& Clarkson, P. (2010). Extending the application of stakeholder influence strategies to environmental disclosures: An exploratory study from a developing country. Accounting, Auditing \& Accountability Journal, 23(8), 1032-59.

21. Emtairah, T., Al-Ashaikh, A., \& Al-Badr, A. (2009). Contexts and corporate social responsibility: the case of Saudi Arabia. International Journal of Sustainable Society, 1(4), 325-46.

22. Fadaak, T. (2010). Poverty in the Kingdom of Saudi Arabia: an exploratory study of poverty and female-headed households in Jeddah City. Social Policy and Administration, 44(6), 689-707.

23. Fernando, A., \& Pandey, I. (2012). Corporate social responsibility reporting: a survey of listed Sri Lankan companies. Journal for International Business and Entrepreneurship Development, 6(2), 172-87.

24. Fifka, M. S. (2013). Corporate responsibility reporting and its determinants in comparative perspective - a review of the empirical literature and a metaanalysis. Business Strategy and the Environment, 22(1), 1-35.

25. Frost, G., Jones, S., Loftus, J., \& Van Der Laan, S. (2005). A survey of sustainability reporting practices of Australian reporting entities. Australian Accounting Review, 15(1), 89-96.

26. Gao, Y. (2011). CSR in an emerging country: a content analysis of CSR reports of listed companies. Baltic Journal of Management, 6(2), 263-91.

27. Garbarino, M. S. (1983). Sociocultural theory in anthropology. A short history. Long Grove: Waveland Press Inc.

28. Global Insights. Corporate responsibility, philanthropy and development, Policy Brief 08, 2016:13 January. 2013. [online at https://www.sussex.ac.uk/ webteam/gateway/file.php?name=corporate-responsibility-anddevelopment-global-insights-08-web.pdf\&site=11]

29. Goger, A. (2013). The making of a 'business case' for environmental upgrading: Sri Lanka's eco-factories. Geoforum, 47, 73-83.

30. Gray, R. (2006). Does sustainability reporting improve corporate behaviour?: Wrong question? Right time? Accounting and Business Research, 36(sup1), 65-88.

31. Guan, J., \& Noronha, C. (2013). Corporate social responsibility reporting research in the Chinese academia: a critical review. Social Responsibility Journal, 9(1), 35-55.

32. Gurvitsh, N., \& Sidorova, I. (2012). Environmental and social accounting disclosures as a vital component of sustainability reporting integrated into annual reports of the Baltic companies for the Years 2007-2011: Based on companies listed on NASDAQ OMX Baltic Main List as of June 2012. GSTF Business Review (GBR), 2(1), 38-44.

33. HDI. Human Development Report 2013. United Nations Development Programm; 2013. Available at: http://hdr.undp.org/en/media/HDR_2013_EN_ complete.pdf

34. Hunter, M. L., \& Van Wassenhove, L. N. (2011). Hayleys PLC: corporate responsibility as stakeholder relations. The Journal of Management Development, 30(10), 968-84.

35. IMF. (2015). World economic outlook, April 2015. Washington, DC: International Monetary Fund.

36. Khan, M. H. U. Z. (2010). The effect of corporate governance elements on corporate social responsibility (CSR) reporting: Empirical evidence from private commercial banks of Bangladesh. International Journal of Law and Management, 52(2), 82-109.

37. Landry, P. F. (2008). Decentralized authoritarianism in China. New York: Cambridge University Press.

38. Lieber, A. (2013). The Chinese ideology: reconciling the politics with the economics of contemporary reform. Journal of Chinese Political Science, 18(4), 335-53.

39. Lund-Thomsen, P., Lindgreen, A., \& Vanhamme, J. (2016). Industrial clusters and corporate social responsibility in developing countries: what we know, what we do not know, and what we need to know. Journal of Business Ethics, 133(1), 9-24.

40. Maali, B., Casson, P., \& Napier, C. (2006). Social reporting by islamic banks. Abacus, 42(2), 266-89. 
41. Mandurah, S., Khatib, J., \& Al-Sabaan, S. (2012). Corporate social responsibility among Saudi Arabian Firms: an empirical investigation. Journal of Applied Business Research, 28(5), 1049-57.

42. Marinellin, M. (2012). Disembodied Words: The Ritualistic quality of political discourse in the era of Jiang Zemin. In P. Chilton, H. Tian, \& R. Wodak (Eds.), Discourse and Socio-political Transformations in Contemporary China. Amsterdam: John Benjamins Publishing Co.

43. Marios, I. K., \& Tor, B. (2007). Corporate social responsibility: an exploratory study in the United Arab Emirates. SAM Advanced Management Journal, 72(4), 9-20,2.

44. Mathews, M. R. (1997). Twenty-five years of social and environmental accounting research - Is there a silver jubilee to celebrate? Accounting Auditing and Accountability Journal, 10(4), 481-531.

45. Mattlin, M. (2009). Chinese Strategic state-owned enterprises and ownership control. BICCS Asia Paper, 4(6), 1-28.

46. Minnee, F., Shanka, T., Taylor, R., \& Handley, B. (2013). Exploring corporate responsibility in Oman - social expectations and practice. Social Responsibility Journal, 9(2), 326-39.

47. Mishra, S., \& Suar, D. (2010). Does corporate social responsibility influence firm performance of Indian companies? Journal of Business Ethics, 95(4), 571-601.

48. Momin, M. A., \& Parker, L. D. (2013). Motivations for corporate social responsibility reporting by MNC subsidiaries in an emerging country: The case of Bangladesh. The British Accounting Review, 45(3), 215-28.

49. Morhardt, J. E. (2010). Corporate social responsibility and sustainability reporting on the internet. Business Strategy and the Environment, 19, 436-52.

50. Muttakin, M. B., Khan, A., \& Subramaniam, N. (2015). Firm characteristics, board diversity and corporate social responsibility: evidence from Bangladesh. Pacific Accounting Review, 27(3), 353-72.

51. Nalband, N. A., \& Al-Amri, M. S. (2013). Corporate social responsibilityperception, practices and performance of listed companies of Kingdom of Saudi Arabia. International Business Journal incorporating Journal of Global Competitiveness, 23(3), 5-5.

52. Naser, K., Al-Hussaini, A., Al-Kwari, D., \& Nuseibeh, R. (2006). Determinants of corporate social disclosure in developing countries: the case of Qatar. Advances in International Accounting, 19(6), 1-23.

53. Naser, K., \& Hassan, Y. (2013). Determinants of corporate social responsibility reporting: evidence from an emerging economy. Journal of Contemporary Issues in Business Research, 3(2), 56-74.

54. Othman, R., \& Ameer, R. (2009). Corporate social and environmental reporting: Where are we heading? A survey of the literature. International Journal of Disclosure and Governance, 6(4), 298-320.

55. Patten, D. M. (2002). The relation between environmental performance and environmental disclosure: a research note. Accounting, Organizations and Society, 27(8), 763-73.

56. Qasim, Z., Muralidharan, P., Ramaswamy, G. 2011. Corporate social responsibility and impact of CSR Practices in the United Arab Emirates. Paper presented at International Conference on Technology and Business Management March.

57. Ramady, M. A. (2010). The Saudi Arabian economy: policies, achievements and challenges. New York: Springer.

58. Raman, S. R. (2006). Corporate social reporting in India-a view from the top. Global Business Review, 7(2), 313-24

59. Ronnegard, D. (2013). CSR in Saudi Arabia: Far behind or another path? Fountainebleau: INSEAD.

60. Rostow, W. W. (1962). The stages of economic growth. London: Cambridge University Press.

61. Rowe, A. L., \& Guthrie, J. (2009). Institutional Cultural Norms of Chinese Corporate Environmental Reporting.' Interdisciplinary Perspectives on Accounting Conference. Austria: University Innsbruck.

62. Sahay, A. (2004). Environmental reporting by Indian corporations. Corporate Social Responsibility and Environmental Management, 11(1), 12-22.

63. Sangeetha, K., \& Pria, S. (2012). Resources affecting banks' CSR in sultanate of Oman: a stakeholders' perspective. Journal of Business Ethics and Organization Studies, 17(1), 31-40

64. Senaratne, S., Liyanagedara, K. (2012). Corporate sustainability reporting in Sri Lanka. Paper presented at International Conference on Business Management.

65. Silvia, R., \& Belen, F.-F. (2013). Effect of Hofstede's cultural differences in corporate social responsibility disclosure. International Journal of Information Systems and Social Change (IJISSC), 4(1), 68-84.
66. Situ, H., \& Tilt, C. A. (2012). Chinese government as a determinant of corporate environmental reporting: a study of large Chinese listed companies. Journal of the Asia Pacific Centre for Environmental Accountability, 18(4), 251-86.

67. Situ, H., Tilt, C. A., Seet, P. S., \& Max, S. (2013). Understanding the impact of Chinese government and other stakeholders on Corporate Environmental Reporting in China. Kobe, Japan: 7th Asia Pacific Interdisciplinary Research in Accounting Conference (APIRA). Available at: http://www.apira2013.org/ proceedings/.

68. Situ, H., Tilt, CA., Seet, PS. (2015). Corporate Environmental Reporting (CER) in China: A Stakeholder Perspective. Paper presented at Australasian Conference on Social and Environmental Accounting Research.

69. Siwar, C., \& Hossain, M. (2009). An analysis of Islamic CSR concept and the opinions of Malaysian managers. Management of Environmental Quality, 20(3), 290-98.

70. Sudarma, M., Triyuwono, I., Ludigdo, U., Meutia, I. (2010). Qualitative approach to build the concept of social responsibility disclosures based on Shari'ah Enterprise Theory.

71. Sumiani, Y., Haslinda, Y., \& Lehman, G. (2007). Environmental reporting in a developing country: a case study on status and implementation in Malaysia. Journal of Cleaner Production, 15(10), 895-901.

72. Tilt, C. A. (2001). The content and disclosure of Australian corporate environmental policies. Accounting Auditing and Accountability Journal, 14(2), 190-212.

73. UNDP. Human Development Report (DHR). 2015. [online at http://hdr.undp. org/en]. Accessed 1 Feb 2016.

74. United Nations, D. o. E. a. S. A. Population Trends. 2013. http://www.un.org/ en/development/desa/population/theme/trends/index.shtml: United Nations: Department of Economic and Social Affairs. Accessed 12 Feb 2016.

75. Van Dijk, T. A. (2009). Critical Discourse Analysis: A Sociocognitive Approach. In Methods of Critical Discourse Analysis (2nd ed., pp. 62-86). Los Angeles: SAGE Publication Ltd.

76. Visser, W. (2008).Corporate social responsibility in developing countries. The Oxford handbook of corporate social responsibility. p. 473-79

77. Wang, L., \& Juslin, H. (2009). The impact of Chinese culture on corporate social responsibility: the harmony approach. Journal of Business Ethics, 88, 433-51.

78. Wijesinghe, KN. (2012). Current context of disclosure of corporate social responsibility in Sri Lanka.

79. World Bank. Macroeconomics \& Economic Growth in South Asia. nd. http:// go.worldbank.org/6GS5XVH100. Accessed 5 Feb 2016.

80. Wijesinha A. 'Can Sri Lanka build a prosperous post-war future?', 2014; [online at http://www.eastasiaforum.org/2014/06/10/can-sri-lanka-build-aprosperous-post-warfuture/]. Accessed 12 Feb 2016.

81. WPR 2015. Sri Lanka Population 2015. http://worldpopulationreview.com/ countries/sri-lanka-population/: World Population Review. Accessed 20 Jan 2016.

82. Zhang, Q. (2012). The discursive construction of the social stratification order in reforming China. In P. Chilton, H. Tian, \& R. Wodak (Eds.), Discourse and socio-political transformations in Contemporary China (pp. 19-37). Amesterdam: John Benjamins Publishing Co.

83. Zhao J. Funding energy industry: International Finance Corporation invest in Chinese Green Energy (为能源业提供融资动力:国际金融公司投资中国绿 色能源), China WTO Tribune. 2011. p. 10.

84. Zheng, Y. (2010). China model: experience and dilemma (中国模式:经验与困 局). Zhengzhou, China: Zhengzhou People Publishing House.

\section{Submit your manuscript to a SpringerOpen ${ }^{\circ}$ journal and benefit from:}

- Convenient online submission

- Rigorous peer review

- Immediate publication on acceptance

- Open access: articles freely available online

- High visibility within the field

- Retaining the copyright to your article

Submit your next manuscript at $>$ springeropen.com 